\title{
Water Properties Influencing the Abundance and Diversity of Denitrifiers on Eichhornia crassipes Roots: A Comparative Study from Different Effluents around Dianchi Lake, China
}

\author{
Neng Yi, Yan Gao, Zhenhua Zhang, Hongbo Shao, and Shaohua Yan \\ Institute of Agricultural Resources and Environment and Institute of Agro-biotechnology, Jiangsu Academy of Agricultural Sciences, \\ Nanjing 210014, China
}

Correspondence should be addressed to Hongbo Shao; shaohongbochu@126.com and Shaohua Yan; shyan@jaas.ac.cn

Received 20 December 2014; Revised 1 April 2015; Accepted 1 April 2015

Academic Editor: Ferenc Olasz

Copyright (C) 2015 Neng Yi et al. This is an open access article distributed under the Creative Commons Attribution License, which permits unrestricted use, distribution, and reproduction in any medium, provided the original work is properly cited.

\begin{abstract}
To evaluate effects of environmental conditions on the abundance and communities of three denitrifying genes coding for nitrite (nirK, nirS) reductase and nitrous oxide (nosZ) reductase on the roots of Eichhornia crassipes from 11 rivers flowing into the northern part of Dianchi Lake. The results showed that the abundance and community composition of denitrifying genes on E. crassipes root varied with different rivers. The nirK gene copies abundance was always greater than that of nirS gene on the roots of E. crassipes, suggesting that the surface of E. crassipes roots growth in Dianchi Lake was more suitable for the growth of nirK-type denitrifying bacteria. The DGGE results showed significant differences in diversity of denitrifying genes on the roots of E. crassipes among the 11 rivers. Using redundancy analysis (RDA), the correlations of denitrifying microbial community compositions with environmental factors revealed that water temperature $(T)$, dissolved oxygen (DO), and $\mathrm{pH}$ were relatively important environmental factors to modifying the community structure of the denitrifying genes attached to the root of E. crassipes. The results indicated that the specific environmental conditions related to different source of rivers would have a stronger impact on the development of denitrifier communities on E. crassipes roots.
\end{abstract}

\section{Introduction}

Phytoremediation technology using floating macrophytes (Eichhornia crassipes) performed very well in remediation eutrophic water body since E. crassipes is capable of assimilating large amount of nutrients efficiently [1-3]. During 20102012 , large-scale confined growth of $E$. crassipes was used to remove pollutants (mainly $\mathrm{N}$ and $\mathrm{P}$ ) from Dianchi Lake as well as the rivers connecting to the lake. Dianchi Lake is the sixth largest freshwater lake in China. There are more than 31 rivers, which carried wastewater discharged from different types of sewage treatment plants (STPs), agriculture, and domestic source, flowing into the lake. The macrophytes significantly improved water quality in both inflow rivers and Dianchi Lake [4].

To evaluate the contributions of water hyacinth to the removal of nitrogen from the lake, both assimilation and stimulated denitrification by the macrophyte are important since $\mathrm{N}-15$ tracing experiment in labs indicated that the values of $\mathrm{N}-15$ at.\% excess of $\mathrm{N}_{2}-\mathrm{N}$ production were significantly $(p<0.05)$ higher with the growth of E. crassipes than that without $[5,6]$. The presence of $E$. crassipes roots has positive effect on stimulating the activity, abundance, and diversity of denitrifiers. Studies have reported that plant rhizosphere enhanced bacterial abundance, activity, and diversity [7]. Previous studies also suggested that the root system of floating macrophyte could support the attachment of microorganism and enhance the growth and activity of bacteria for removing organic matter and nutrients [8].

Environmental conditions are also critically important in mediating the activity, abundance, and diversity of bacteria $[9,10]$. The abundance and diversity of denitrifiers on $E$. crassipes roots grown in the rivers receiving wastewater with different water properties may vary with the variation of environmental factors. The abundance of the functional genes and community compositions of denitrifiers can be affected by many factors, such as water temperature, $\mathrm{pH}, \mathrm{DO}$, and nutrient concentrations. In the rivers with different sources of 


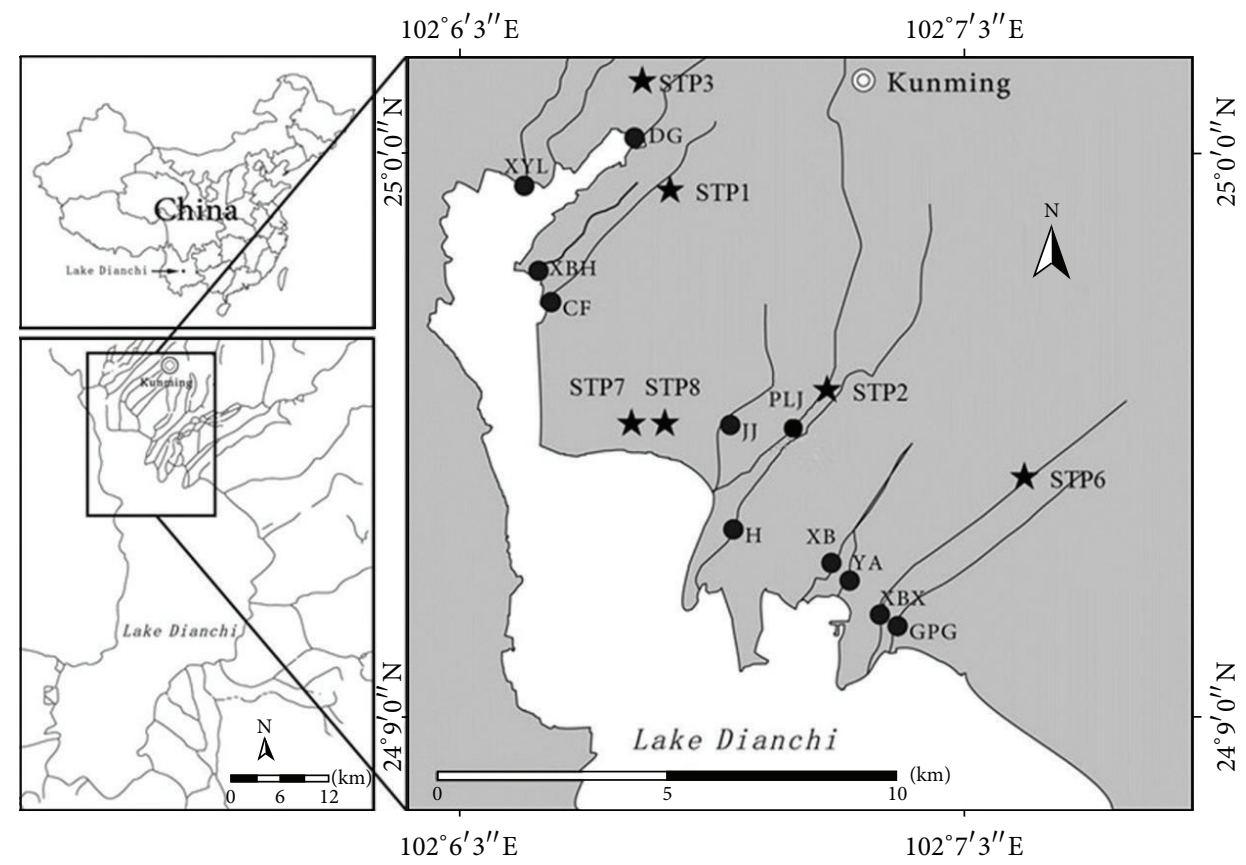

FIGURE 1: Sampling sites in rivers of Dianchi Lake. Black dot $(\bullet)$ is sampling site, and Pentagram $(\star)$ is sewage treatment plants (STP).

condensed pollutants and diverse physiochemical properties, the abundance and diversity of denitrifiers on the E. crassipes roots may be modified in various patterns.

Hence, in the present study, we investigated the abundance and diversity of denitrifying bacteria on E. crassipes roots in 11 rivers with different pollution sources in the north side of Dianchi Lake. It put an emphasis on understanding the interactions between the changes of environmental factors and the abundance and diversity of denitrifying bacteria attached to E. crassipes roots. It was expected that the results would shed some insight on how environmental factors and cultivation of $E$. crassipes mediate denitrification process in different eutrophic rivers flowing into the Dianchi Lake.

\section{Materials and Methods}

2.1. Site Description, Sampling, and Water Properties. A total of 11 rivers around Dianchi Lake located from $24^{\circ} 9^{\prime}$ to $25^{\circ} 0^{\prime}$ latitude and $102^{\circ} 6^{\prime}$ to $102^{\circ} 7^{\prime}$ longitude were investigated (Figure 1). As shown in Figure 1, Xinbaoxiang (XBX), Daguan (DG), Chuanfang (CF), and Panlongjiang (PLJ) rivers receive effluents from sewage treatment plants (STPs). Haihe (H), Guangpugou (GPG), Jinjia (JJ), Xibahe (XBH), and Xinyunliang (XYL) rivers receive raw sewage from industrial, domestic, and agricultural sources. Xiaba (XB) and Yaoan (YA) rivers represent the same sewage origin from the same upstream (not sampled due to water hyacinth not being grown) but different tributaries separated at water treatment wetland named Wujia (not sampled due to water hyacinth not grown).

Water temperature, $\mathrm{pH}$, and dissolved oxygen (DO) were measured in situ using portable meter (YSI ProPlus, USA). One-liter water samples were collected from each site with three replicates at $0-0.5 \mathrm{~m}$ of the water column of the eleven rivers using cylinder sampler in September 25, 2012. Total nitrogen (TN), ammonium $\left(\mathrm{NH}_{4}{ }^{+}\right)$, nitrate $\left(\mathrm{NO}_{3}{ }^{-}\right)$, nitrite $\left(\mathrm{NO}_{2}{ }^{-}\right)$, and total soluble nitrogen (TSN) were analyzed using a SEAL AutoAnalyzer 3 (SEAL Analytical Co., Hampshire, UK). Mixed root samples were collected randomly with three replicates at each sampling site using sterile scissors and forceps and then stored in an ice box and taken back to the laboratory. Fresh roots ( $2 \mathrm{~g})$ of E. crassipes were transferred into $200 \mathrm{~mL}$ sterile water. Bacteria attached to E. crassipes roots were detached by vigorous shaking for $30 \mathrm{~min}(18.3 \mathrm{~Hz}$, Thermomixer Eppendorf) and filtered through a $0.45 \mu \mathrm{m}$ sterile filter. The resultant filtrates were filtered through $0.22 \mu \mathrm{m}$ Millipore membrane filters using a vacuum air pump and the membranes stored at $-80^{\circ} \mathrm{C}$ for DNA extraction [5].

2.2. DNA Extraction. All the abovementioned membranes were cut into pieces with sterile scissors and used immediately for DNA extraction, which was performed using an E.Z.N.A. Water DNA Kit (OMEGA Bio-Tek Inc., Doraville, GA, USA) by following the manufacturer's instructions. The extracted DNA was stored in a $-20^{\circ} \mathrm{C}$ freezer [5].

\subsection{Real-Time Polymerase Chain Reaction ( $q P C R$ ) Assay.} Real-time quantitative PCR was performed to estimate the denitrifying bacteria abundance using the primers listed in Table 1. Real-time polymerase chain reaction (qPCR) was performed on ABI 7500 real-time System (Life Technologies, USA). Amplification was performed in triplicate in a total volume of $20 \mu \mathrm{L}$ reaction mixtures by using SYBR Premix Ex TaqTM (TIiRNaseH Plus) qPCR Kit as described by the suppliers (Takara Bio, Dalian, China). For each assay, three different PCR conditions were performed separately 
TABLE 1: Primers used for the qPCR and DGGE.

\begin{tabular}{|c|c|c|c|}
\hline Gene & & Primers & Thermal profile \\
\hline \multirow{3}{*}{$\operatorname{nos} Z$} & \multirow{3}{*}{$\begin{array}{l}\text { for qPCR } \\
\text { for DGGE }\end{array}$} & nosZ-F [45] & CGYTGTTCMTCGACAGCCAG \\
\hline & & nosZ1622R [45] & CGSACCTTSTTGCCSTYGCG \\
\hline & & nosZ1622R-GC [46] & $\begin{array}{l}\text { GGCGGCGCGCCGCCCGCCCCGCCCCCGTCGCCC- } \\
\text { CGSACCTTSTTGCCSTYGCG }\end{array}$ \\
\hline \multirow{3}{*}{ nirs } & \multirow{3}{*}{$\begin{array}{l}\text { for qPCR } \\
\text { for DGGE }\end{array}$} & nirS-Cd3Af [47] & GTSAACGTSAAGGARACSGG \\
\hline & & nirS-R3cd [47] & GASTTCGGRTGSGTCTTGA \\
\hline & & nirS-R3cd-GC [48] & $\begin{array}{l}\text { GGCGGCGCGCCGCCCGCCCCGCCCCCGTCGCCC- } \\
\text { GASTTCGGRTGSGTCTTGA }\end{array}$ \\
\hline \multirow{3}{*}{ nirK } & \multirow{3}{*}{$\begin{array}{l}\text { for qPCR } \\
\text { for DGGE }\end{array}$} & nirK FlaCu [49] & ATCATGGTSCTGCCGCG \\
\hline & & $\operatorname{nirK} \mathrm{R} 3 \mathrm{Cu}[49]$ & GCCTCGATCAGRTTGTGGTT \\
\hline & & $\operatorname{nirK} \mathrm{R} 3 \mathrm{Cu}-\mathrm{GC}[49]$ & $\begin{array}{l}\text { GGCGGCGCGCCGCCCGCCCCGCCCCCGTCGCCC- } \\
\text { GCCTCGATCAGRTTGTGGTT }\end{array}$ \\
\hline
\end{tabular}

for the same sample by varying annealing temperature at either $54^{\circ} \mathrm{C}$ (nirS- Cd3Af/nirS-R3cd and nosZ-F/nosZ-1622R) or $58^{\circ} \mathrm{C}$ (nirK-FlaCu/nirK-R3Cu). The qPCR amplification was performed as follows: initial denaturation at $95^{\circ} \mathrm{C}$ for $2 \mathrm{~min}$, followed by 35 cycles consisting of denaturation step at $95^{\circ} \mathrm{C}$ for $5 \mathrm{~s}$, varying annealing temperature for $30 \mathrm{~s}$, and elongation at $72^{\circ} \mathrm{C}$ for $30 \mathrm{~s}$. The data were collected during the $72^{\circ} \mathrm{C}$ for $30 \mathrm{~s}$ step. Data was analyzed using the ABI 7500 software (Version 2.0.6, Life Technologies, USA). The parameter $\mathrm{Ct}$ (threshold cycle) was determined as the cycle number at which a statistically significant increase in the reporter fluorescence was detected. The standard curves for real-time PCR assays were developed as previously described [5].

\subsection{PCR Amplification Denaturing Gradient Gel Electrophore-} sis (DGGE) Analysis. For denaturing gradient gel electrophoresis (DGGE) analysis, the PCR was performed in reaction mixtures including $1 \mu \mathrm{L}$ of template DNA, $5 \mu \mathrm{L}$ of $10 \times$ PCR buffer, $1 \mu \mathrm{L}$ of dNTPs $(10 \mathrm{mM}$ each), $1 \mu \mathrm{L}$ of each primer $(20 \mu \mathrm{M})$ (Table 1$)$, and $2 \mathrm{U}$ of Taq polymerase (Takara Bio, Dalian, China) and adjusted to a final volume of $50 \mu \mathrm{L}$ with sterile deionized water. The reaction was performed in a Bio-Rad C1000 thermal cycler (Bio-Rad, USA) using different cycling conditions. The nirK gene (F1aCu/R3Cu-GC) PCR program was carried out with an initial denaturation at $94^{\circ} \mathrm{C}$ for $3 \mathrm{~min}$, followed by 32 cycles of $94^{\circ} \mathrm{C}$ for $30 \mathrm{~s}, 58^{\circ} \mathrm{C}$ for $30 \mathrm{~s}$, and $72^{\circ} \mathrm{C}$ for $45 \mathrm{~s}$, followed by $72^{\circ} \mathrm{C}$ for $10 \mathrm{~min}$, and ended at $10^{\circ} \mathrm{C}$. The touchdown PCR amplification of nirS (Cd3Af/R3cd-GC) and nosZ (nosZ-F/nosZ1622R-GC) was performed as follows: $94^{\circ} \mathrm{C}$ for $2 \mathrm{~min}$, followed by 10 cycles, $94^{\circ} \mathrm{C}$ for $30 \mathrm{~s}$, and $57^{\circ} \mathrm{C}$ for $30 \mathrm{~s}$ in the initial cycle and at decreasing temperatures by $0.5^{\circ} \mathrm{C} /$ cycle until a temperature of $52^{\circ} \mathrm{C}$ was reached in the subsequent cycles. The extension step was performed at $72^{\circ} \mathrm{C}$ for $1 \mathrm{~min}$. After the touchdown program, 30 cycles at $94^{\circ} \mathrm{C}$ for $30 \mathrm{~s}, 53^{\circ} \mathrm{C}$ for $30 \mathrm{~s}$, and $72^{\circ} \mathrm{C}$ for $1 \mathrm{~min}$, followed by $72^{\circ} \mathrm{C}$ for $10 \mathrm{~min}$, and ended at $10^{\circ} \mathrm{C}$.

The amplified products were pooled and resolved on DGGE gels using a Dcode system (Bio-Rad Laboratories, Hercules, USA). The purified PCR products $(30 \mu \mathrm{L})$ of nirS, nirK, and nos $Z$ containing approximately equal amounts of PCR amplicons were loaded onto the $1 \mathrm{~mm}$-thich $6 \%(\mathrm{w} / \mathrm{v})$ polyacrylamide (37.5: 1 , acrylamide : bisacrylamide) gels with denaturing gradients of $50-75 \%$ for $15 \mathrm{~h}$ (nirS), $50-70 \%$ for $12 \mathrm{~h}$ (nirK), and 50-70\% for $15 \mathrm{~h}$ (nosZ) (100\% denaturant contains $7 \mathrm{~mol} / \mathrm{L}$ urea and $40 \%(\mathrm{v} / \mathrm{v})$ formamide). The gels were run in $1 \times$ TAE ( $40 \mathrm{mM}$ Tris-acetate and $1 \mathrm{mM}$ EDTA) at $100 \mathrm{~V}$ and $60^{\circ} \mathrm{C}$. The gel was silver-stained using protocol [11]. Polaroid pictures of the DGGE gels were scanned using an Epson Perfection V700 Photo scanner (Seiko Epson Corporation, Nagano, Japan). DGGE profiles were digitized after average background subtraction for the entire gel using Quantity One software (Version 4.5, Bio-Rad, USA) as previously described [5]. Digitized information from the DGGE banding profiles was used to calculate the diversity indices such as richness $(S)$, which was determined from the number of bands in each lane, and Shannon-Wiener Index $(H)$, which was calculated from $H=-\sum P_{i} \times \ln P_{i}$ [12], where $P_{i}$ is the importance probability of the bands in a gel lane, calculated as $P_{i}=n_{i} / N$, where $n_{i}$ is the intensity of a band and $N$ is the sum of intensities of all bands.

2.5. Data Analysis. Three replicates were used in all parameter analyses. Data presented as mean values $\pm \mathrm{SD}$. One way analysis of variance (ANOVA) followed by $S-N-K$-test was performed to check for quantitative differences between samples; $P<0.005$ was considered to be statistically significant. All statistical analyses were done using SPSS software.

The relative intensity of a specific band was transformed according to the sum of intensities of all bands in a pattern [13]. Redundancy analysis (RDA) for community ordination was conducted using CANOCO (version 4.5, Centre for Biometry, Wageningen, Netherlands) for Windows using relative band intensity data obtained from the Quantity One analysis [14]. Eight environmental parameters, including water temperature, $\mathrm{pH}, \mathrm{DO}$, ammonia, nitrate, nitrite, total nitrogen, and total soluble nitrogen, were selected to perform RDA-based variance inflation factor (VIF) analysis with 499 unrestricted permutations to statistically evaluate the significance of the first canonical axis and of all canonical axes together. Statistical significance was kept at $P<0.05$ for all analyses. 


\section{Results}

3.1. Water Properties. The corresponding environmental parameters (Table 2) of the eleven rivers represented their own properties of different pollution sources. The water from STP sites was characterized by relatively high concentrations of nitrate (4.79-12 $\mathrm{mg} \mathrm{L}^{-1}$ ) and low concentrations of ammonia nitrogen $\left(0.06-1.98 \mathrm{mg} \mathrm{L}^{-1}\right)$ and organic matter, which had contrary properties comparing to those rivers receiving raw sewage from industrial, domestic, and agricultural sources. The XB and YA rivers had similar characteristics to those rivers receiving water from STP but lower dissolved oxygen and higher ammonia nitrogen.

3.2. Quantification of Denitrifying Genes (nirK, nirS, nosZ). The results showed that the abundance of nirK, nirS, and nos $Z$ gene copies per gram fresh root ranged from $4.13 \times 10^{7}$ to 6.11 $\times 10^{8}, 1.45 \times 10^{8}$ to $1.99 \times 10^{8}$, and $2.20 \times 10^{8}$ to $2.20 \times 10^{10}$, respectively (Figure 2). The nirK and nirS abundance on the roots of $E$. crassipes in YA river and XB river were significantly higher than those in other rivers $(P<0.05)$. The highest abundance of nos $Z$ was observed on the root sample in JJ river. The lowest abundance of nirK and nos $Z$ type denitrifiers were determined on the root sample from DG river. The nirK, nirS, and nos $Z$ copy abundance varied between sites indicated that different pollution source would influence the abundance of denitrifiers in rivers.

The highest abundance ratio (125.34) of nos $Z /($ nirK + nirS) occurred in JJ river, followed by GPG (39.75), while the lowest ratio was in XYL river (1.43), and the ratios in other rivers were similar, ranging from 3.26 to 8.38 . However, the nirK/nirS ratio in all samples ranged from 1.70 to 6.60 .

To explain the relationship between environmental factors and the abundance of nirK, nirS, and nos $Z$, the gene copy numbers of three denitrifiers and eight parameters were explored by redundancy analysis (Figure 3 ). The gray circle area implies a positive correlation and the white circle area implies a negative correlation. The larger the circle area, the greater the impact corresponding to the changes in environmental factors that would have influenced the denitrifiers. Denitrifier lines at the end in the gray circle had positive regression coefficients for that environmental variable with the corresponding $t$-value larger than 2.0. The results showed that the temperature, $\mathrm{pH}$, and nitrate circle areas were larger than other environmental factors, which indicated that temperature, $\mathrm{pH}$, and nitrate circle greatly affected the nirS, nirK, and nos $Z$ abundance than other factors.

The abundance of nirK and nirS was positively correlated with water temperature, nitrate, and nitrite concentrations and was negatively correlated with the other factors $(\mathrm{pH}$, DO, DTN, TN, and ammonium). The abundance of nos $Z$ was negatively correlated with water temperature and was positively correlated with the $\mathrm{pH}$ and $\mathrm{DO}$, while there were no significant correlations with other factors.

3.3. DGGE Fingerprints of nirK, nirS, and nosZ Genes. Only one of the three replicates of DGGE profiles was listed for
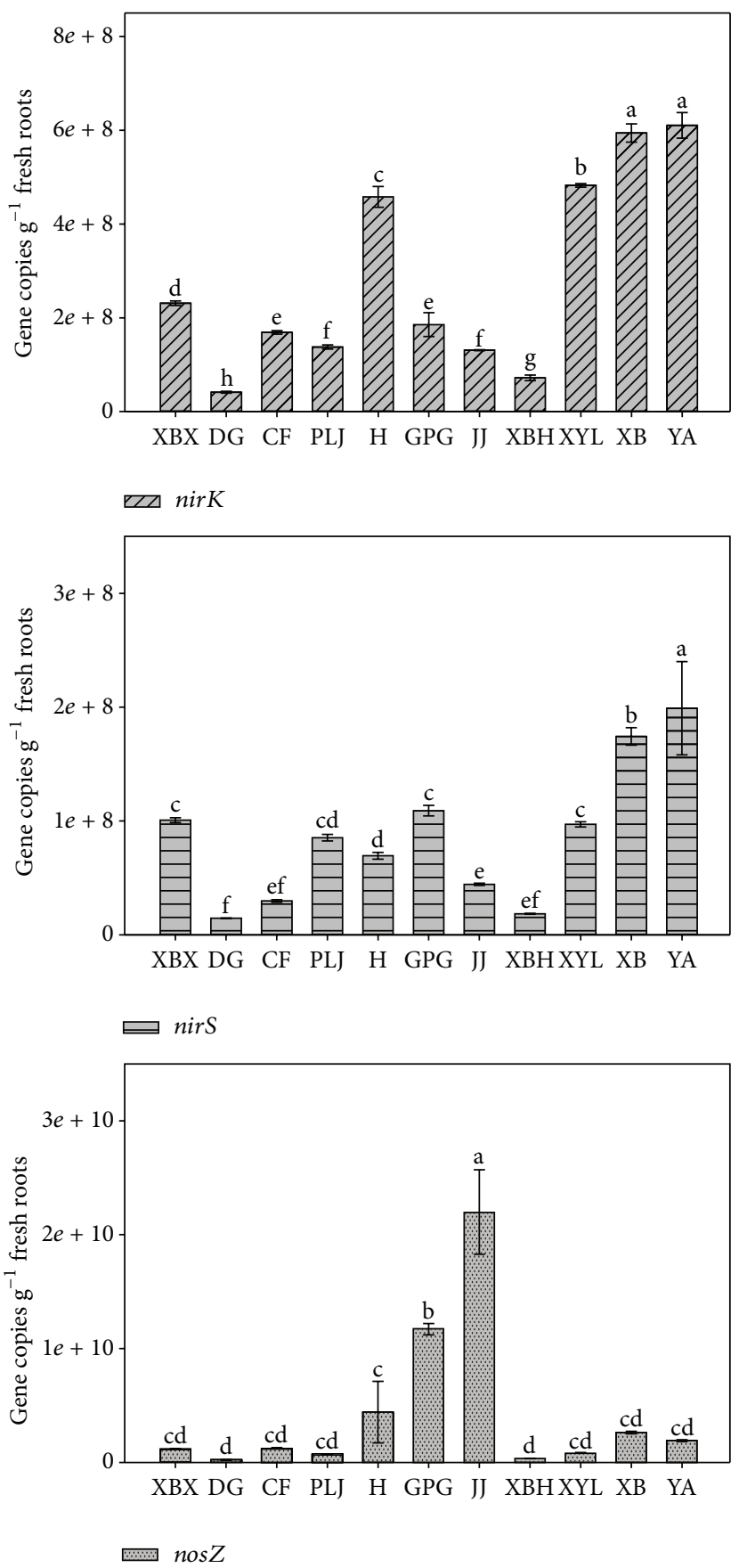

FIgUre 2: Abundance of nirS, nirK, and nosZ genes on the root of E. crassipes. Error bars indicate standard deviations $(n=3)$. The different letters indicate significant differences $(P<0.05)$.

each gene type to illustrate resolution. However, all the three replicates of the profiles were digitized and were used in statistics analysis.

3.4. Richness and Diversity of nirK, nirS, and nosZ on the Root of E. crassipes. The Shannon indices $(H)$ calculated from DGGE gels ranged from 2.23 to 2.90 for nirK, 2.08 to 2.69 for nirS, and 2.11 to 2.73 for nos $Z$, which showed that high diversity of denitrifier (nirK, nirS, and nos Z) genes on the root 


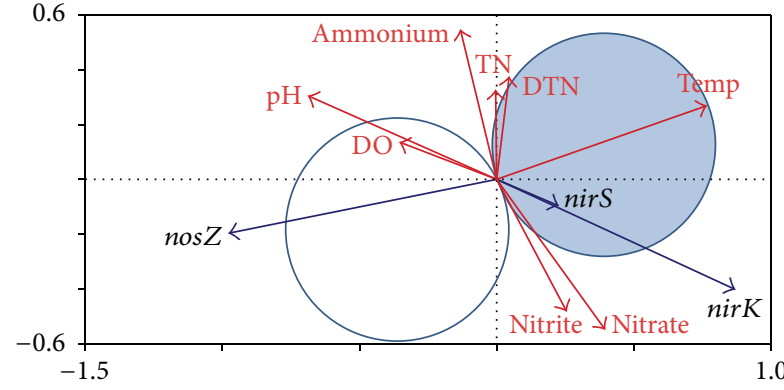

(a) Temp

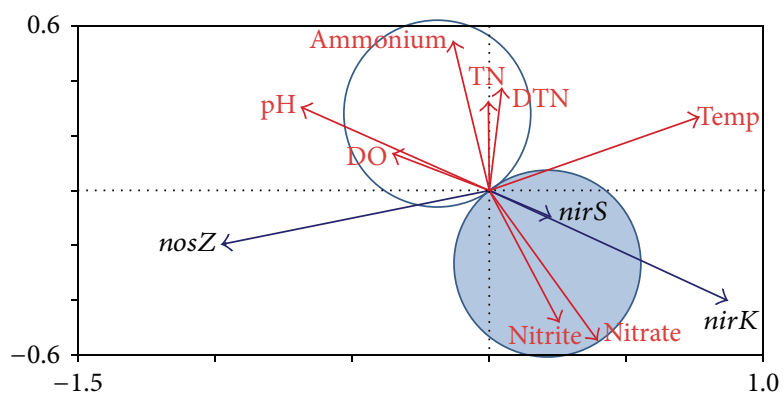

(c) Nitrate

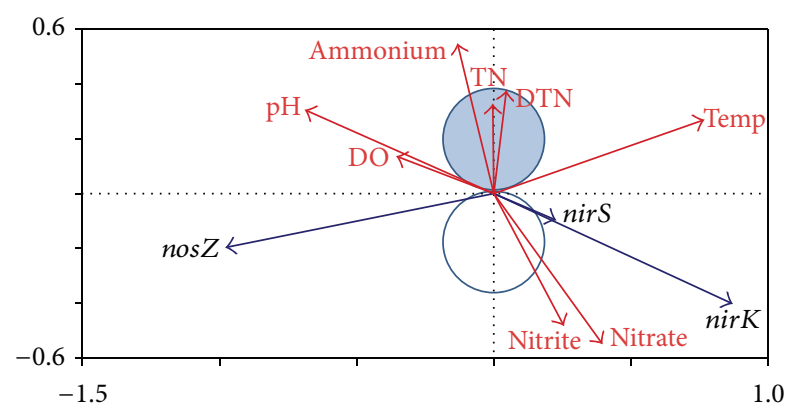

(e) DTN

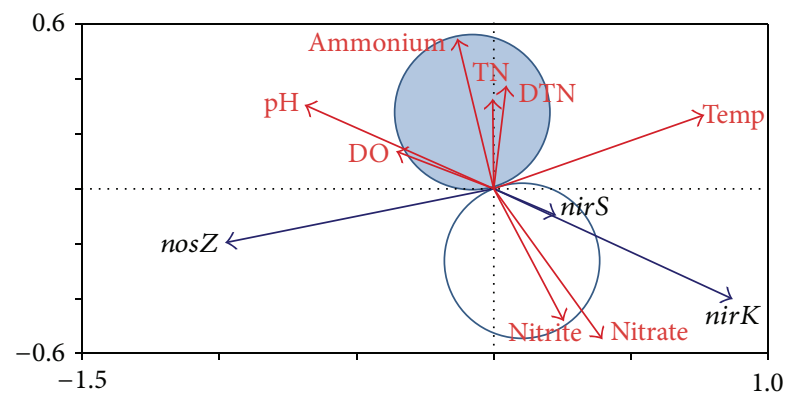

(g) Ammonium

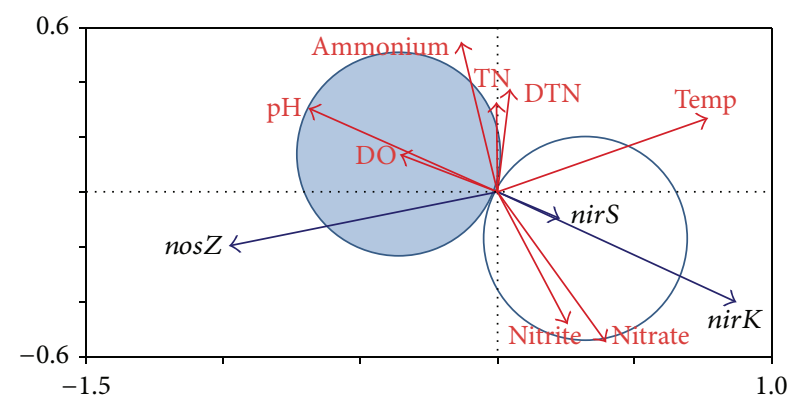

(b) $\mathrm{pH}$

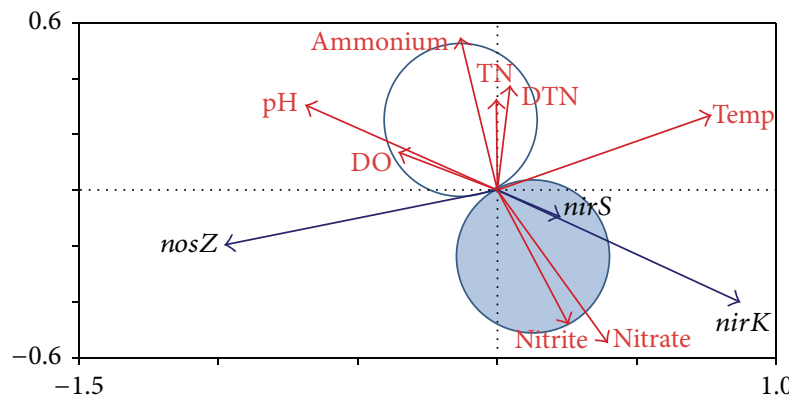

(d) Nitrite

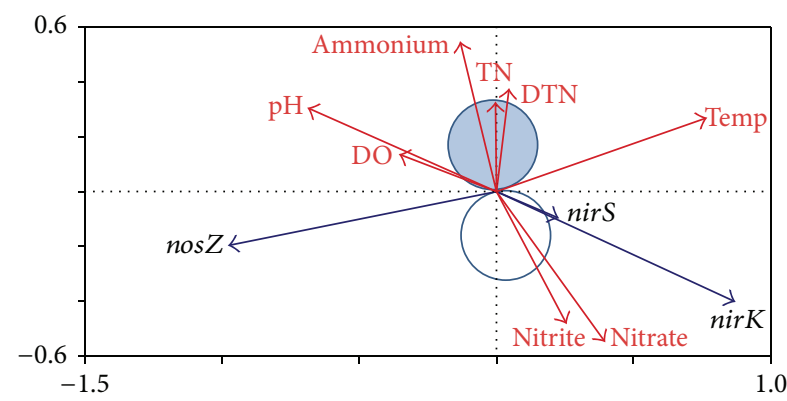

(f) $\mathrm{TN}$

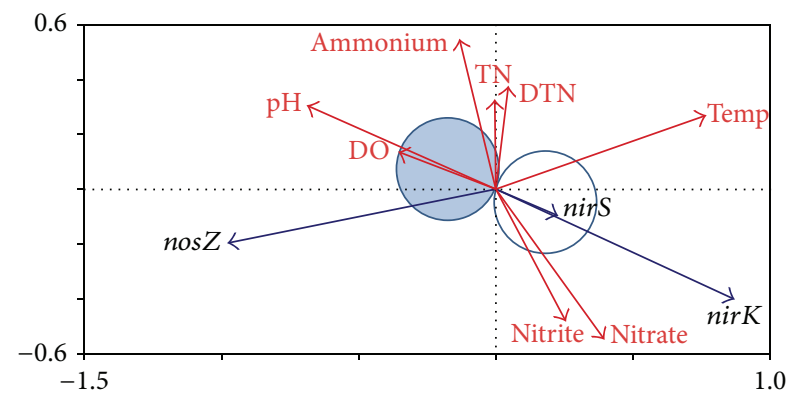

(h) DO

Figure 3: Redundancy analysis $t$-value biplots of environmental factors Temp, pH, nitrate, nitrite, DTN, TN, DO, and ammonium and abundance of nirK, nirS, and nosZ genes.

of E. crassipes (Table 3). The significant differences among them were observed statistically $(P<0.05)$. With respect to the richness and diversity of denitrifier communities in all sites, similar trends emerged with low richness and diversity of nirK and nirS genes in XBX and DG rivers, which mainly received effluent from STPs. Next trends were in the $\mathrm{H}, \mathrm{JJ}$, and $\mathrm{XBH}$ rivers with relatively higher richness and diversity of
nirK and nirS genes, which were less impacted by the effluent from STPs. The highest richness and diversity of nirK showed in the XB and YA rivers, which received wastewater after flowing through a wetland incubation on the water way. The richness and diversity of nos $Z$, which was mainly impacted by temperature, gave a similar trend for all rivers due to the fact that temperature did not vary too much in all sites. 
TABLE 2: Water properties of the rivers at Dianchi Lake (mean \pm SD).

\begin{tabular}{|c|c|c|c|c|c|c|c|c|}
\hline Rivers & $\begin{array}{c}\mathrm{NO}_{3}^{-} \\
\left(\mathrm{mg} \mathrm{L}^{-1}\right)\end{array}$ & $\begin{array}{c}\mathrm{NO}_{2}^{-} \\
\left(\mathrm{mg} \mathrm{L}^{-1}\right)\end{array}$ & $\begin{array}{c}\mathrm{NH}_{4}^{+} \\
\left(\mathrm{mg} \mathrm{L}^{-1}\right)\end{array}$ & $\begin{array}{c}\mathrm{TN} \\
\left(\mathrm{mg} \mathrm{L}^{-1}\right)\end{array}$ & $\begin{array}{c}\mathrm{TSN} \\
\left(\mathrm{mg} \mathrm{L}^{-1}\right)\end{array}$ & $\begin{array}{c}\mathrm{DO} \\
\left(\mathrm{mg} \mathrm{L}^{-1}\right)\end{array}$ & $\mathrm{pH}$ & $T\left({ }^{\circ} \mathrm{C}\right)$ \\
\hline XBX & $4.79 \pm 0.39$ & $0.25 \pm 0.02$ & $0.69 \pm 0.07$ & $7.44 \pm 0.19$ & $6.54 \pm 0.32$ & $2.15 \pm 0.15$ & $7.83 \pm 0.06$ & $19.60 \pm 0.00$ \\
\hline DG & $12.00 \pm 0.67$ & $0.46 \pm 0.00$ & $0.10 \pm 0.02$ & $12.91 \pm 0.62$ & $12.26 \pm 0.42$ & $2.70 \pm 0.13$ & $7.56 \pm 0.04$ & $22.15 \pm 0.05$ \\
\hline $\mathrm{CF}$ & $5.09 \pm 0.03$ & $0.62 \pm 0.02$ & $1.98 \pm 0.02$ & $8.63 \pm 0.10$ & $7.57 \pm 0.06$ & $3.80 \pm 0.10$ & $7.90 \pm 0.06$ & $21.75 \pm 0.05$ \\
\hline PLJ & $5.86 \pm 0.01$ & $0.10 \pm 0.00$ & $0.06 \pm 0.02$ & $8.08 \pm 0.19$ & $6.45 \pm 0.08$ & $2.80 \pm 0.00$ & $8.03 \pm 0.00$ & $19.70 \pm 0.00$ \\
\hline$\overline{\mathrm{H}}$ & $0.16 \pm 0.02$ & $0.09 \pm 0.00$ & $18.48 \pm 2.30$ & $23.69 \pm 0.79$ & $19.84 \pm 1.91$ & $0.20 \pm 0.10$ & $7.90 \pm 0.01$ & $18.80 \pm 0.00$ \\
\hline GPG & $0.08 \pm 0.02$ & $0.04 \pm 0.01$ & $19.54 \pm 0.19$ & $23.66 \pm 0.16$ & $21.27 \pm 0.07$ & $0.20 \pm 0.10$ & $7.83 \pm 0.00$ & $17.90 \pm 0.00$ \\
\hline JJ & $0.43 \pm 0.02$ & $0.15 \pm 0.00$ & $5.12 \pm 0.50$ & $8.14 \pm 0.54$ & $6.86 \pm 0.37$ & $1.30 \pm 0.10$ & $7.90 \pm 0.01$ & $19.50 \pm 0.00$ \\
\hline $\mathrm{XBH}$ & $5.92 \pm 0.25$ & $0.70 \pm 0.00$ & $0.78 \pm 0.20$ & $8.60 \pm 0.19$ & $6.96 \pm 0.58$ & $0.60 \pm 0.00$ & $7.77 \pm 0.00$ & $21.60 \pm 0.00$ \\
\hline $\mathrm{XYL}$ & $0.08 \pm 0.02$ & $0.05 \pm 0.00$ & $18.72 \pm 3.31$ & $21.40 \pm 2.78$ & $19.95 \pm 3.55$ & $0.45 \pm 0.05$ & $7.78 \pm 0.02$ & $21.55 \pm 0.05$ \\
\hline $\mathrm{XB}$ & $0.56 \pm 0.14$ & $0.17 \pm 0.04$ & $3.03 \pm 0.52$ & $6.35 \pm 1.21$ & $5.60 \pm 0.64$ & $0.55 \pm 0.25$ & $7.78 \pm 0.06$ & $17.95 \pm 0.05$ \\
\hline YA & $8.99 \pm 0.00$ & $0.62 \pm 0.01$ & $2.49 \pm 0.27$ & $15.08 \pm 0.50$ & $11.97 \pm 0.56$ & $1.05 \pm 0.35$ & $7.85 \pm 0.07$ & $17.60 \pm 0.10$ \\
\hline
\end{tabular}

TABLE 3: Shannon $(H)$ and richness $(S)$ values of nirK, nirS, and nosZ genes.

\begin{tabular}{lcccccc}
\hline Rivers & \multicolumn{2}{c}{ nirK } & \multicolumn{2}{c}{ nirS } & nosZ & S \\
\hline XBX & $11.00 \pm 1.00$ & $2.25 \pm 0.20$ & $11.67 \pm 0.58$ & $2.18 \pm 0.06$ & $10.67 \pm 0.58$ & $2.11 \pm 0.10$ \\
DG & $13.67 \pm 1.15$ & $2.23 \pm 0.21$ & $11.67 \pm 1.53$ & $2.15 \pm 0.07$ & $15.67 \pm 0.58$ & $2.56 \pm 0.20$ \\
CF & $16.67 \pm 0.58$ & $2.48 \pm 0.17$ & $15.33 \pm 0.58$ & $2.57 \pm 0.30$ & $17.33 \pm 0.58$ & $2.65 \pm 0.25$ \\
PLJ & $16.67 \pm 1.15$ & $2.54 \pm 0.41$ & $18.67 \pm 1.15$ & $2.65 \pm 0.21$ & $18.00 \pm 1.00$ & $2.73 \pm 0.26$ \\
H & $17.00 \pm 0.00$ & $2.53 \pm 0.45$ & $17.67 \pm 1.53$ & $2.69 \pm 0.31$ & $11.00 \pm 0.00$ & $2.18 \pm 0.16$ \\
GPG & $14.33 \pm 1.53$ & $2.36 \pm 0.37$ & $17.00 \pm 0.00$ & $2.66 \pm 0.34$ & $16.33 \pm 0.58$ & $2.44 \pm 0.34$ \\
JJ & $18.66 \pm 058$ & $2.59 \pm 0.04$ & $10.33 \pm 1.53$ & $2.08 \pm 0.35$ & $12.33 \pm 0.58$ & $2.25 \pm 0.21$ \\
XBH & $17.67 \pm 0.58$ & $2.71 \pm 0.19$ & $13.33 \pm 0.58$ & $2.26 \pm 0.19$ & $14.67 \pm 0.58$ & $2.45 \pm 0.32$ \\
XYL & $14.33 \pm 1.15$ & $2.38 \pm 0.16$ & $13.00 \pm 0.00$ & $2.56 \pm 0.22$ & $16.33 \pm 0.58$ & $2.64 \pm 0.24$ \\
XB & $21.00 \pm 1.00$ & $2.61 \pm 0.20$ & $17.00 \pm 0.00$ & $2.64 \pm 0.39$ & $14.67 \pm 1.15$ & $2.35 \pm 0.31$ \\
YA & $22.33 \pm 0.58$ & $2.90 \pm 0.56$ & $15.33 \pm 0.00$ & $2.54 \pm 0.11$ & $13.00 \pm 0.00$ & $2.29 \pm 0.15$ \\
\hline
\end{tabular}

3.5. Relationship between Environment Matrices and Denitrifier Diversity. To determine to what extent the eight environmental properties affected the three types of denitrifier community compositions, nirK, nirS, and nosZ DGGE fingerprints were evaluated by redundancy analysis (Table 4). The first axis explained $26.9 \%$ of the nirK-type denitrifier diversity, and the second axis explained $21.8 \%$ of the diversity. For nirS-type denitrifier, the first two canonical axes explained $29.5 \%$ and $11.5 \%$ of the variation, respectively. For nos $Z$-type denitrifier, $37.8 \%$ and $13.7 \%$ of the variation were explained by the first two canonical axes (Table 4).

Of the parameters, total $\mathrm{N}, \mathrm{DO}, \mathrm{pH}$, and water temperature appeared to be the relatively important environmental factors for denitrifiers (Table 5). For nirK-type denitrifier, water temperature, $\mathrm{DO}$, and total $\mathrm{N}$ explained $46 \%$ variations of microbial communities, leaving $54 \%$ of the variation unexplained. Variation partitioning analysis showed that water temperature, DO, and total $\mathrm{N}$ separately explained $19 \%$ $(P=0.020), 13 \%(P=0.054)$, and $14 \%(P=0.240)$ of the variation, respectively. For nirS-type denitrifier, water temperature $(18 \%, P=0.066), \mathrm{pH}(10 \%, P=0.304)$, and DO $(8 \%, P=0.038)$ explained $36 \%$ variations of microbial communities, leaving $64 \%$ of the variation unexplained.
Compared to nirS, the total $\mathrm{N}$ rather than $\mathrm{DO}$ was relatively important for nosZ-type denitrifier (Table 5).

The relationships of microbial patterns to environmental variables were summarized in RDA ordination plots (Figures 4(b), 5(b), and 6(b)). The RDA charts (Figure 4(b)) of nirK gene showed four rivers (PLJ, XYL, DG, and CF) grouped into one type, while other four rivers (XBH, XBX, H, and YA) clustered together. Other rivers were located independently; they did not belong to either group. For nirS gene, PLJ, $\mathrm{JJ}$, and CF rivers were similar and grouped into one type, while other three rivers (XBH, XYL, and $\mathrm{XBX}$ ) clustered together. Other rivers were not similar and did not belong to either group (Figure 5(b)). According to the RDA chart (Figure 6(b)) of nos $Z$ gene, DG, H, GPG, and XBH rivers were located independently and did not cluster with any group. However, PLJ, XYL, JJ, and CF rivers clustered into one group, while other three rivers (XB, XBX, and YA) clustered together.

\section{Discussion}

The activity of denitrifying microorganisms leads to significant net removal of dissolved nitrogen from the water, 
TABLE 4: Redundancy analysis results of nirK, nirS, and nosZ DGGE profiles.

\begin{tabular}{|c|c|c|c|c|c|}
\hline Axis & Eigenvalue & $\begin{array}{l}\text { Denitrifier-environment } \\
\text { correlation }\end{array}$ & $\begin{array}{c}\text { Cumulative } \% \text { variation } \\
\text { of denitrifier }\end{array}$ & $\begin{array}{c}\text { Cumulative\% variation of } \\
\text { denitrifier-environment }\end{array}$ & $\begin{array}{c}\text { Sum of all canonical } \\
\text { eigenvalues }\end{array}$ \\
\hline \multicolumn{6}{|c|}{ nirK RDA } \\
\hline Axis 1 & 0.269 & 0.987 & 26.9 & 31.0 & \multirow{4}{*}{0.867} \\
\hline Axis 2 & 0.218 & 0.954 & 48.7 & 56.2 & \\
\hline Axis 3 & 0.141 & 0.944 & 62.8 & 72.5 & \\
\hline Axis 4 & 0.075 & 0.990 & 70.3 & 81.1 & \\
\hline \multicolumn{6}{|c|}{ nirs RDA } \\
\hline Axis 1 & 0.295 & 0.965 & 29.5 & 42.6 & \multirow{4}{*}{0.693} \\
\hline Axis 2 & 0.114 & 0.895 & 41.0 & 59.1 & \\
\hline Axis 3 & 0.099 & 0.780 & 50.8 & 73.3 & \\
\hline Axis 4 & 0.072 & 0.861 & 58.0 & 83.8 & \\
\hline \multicolumn{6}{|c|}{ nos Z RDA } \\
\hline Axis 1 & 0.378 & 0.996 & 37.8 & 48.1 & \multirow{4}{*}{0.786} \\
\hline Axis 2 & 0.136 & 0.973 & 51.5 & 65.5 & \\
\hline Axis 3 & 0.097 & 0.682 & 61.2 & 77.9 & \\
\hline Axis 4 & 0.071 & 0.971 & 68.4 & 87.0 & \\
\hline
\end{tabular}

TABLE 5: Eigenvalues, $F$ values, and $P$ values obtained from the partial RDAs testing the influence of the significant water properties on the denitrifying bacterial community composition.

\begin{tabular}{|c|c|c|c|c|c|}
\hline Samples & Environmental variables & Eigenvalue & \% variation explains solely & $F$ value & $P$ value \\
\hline \multirow{4}{*}{ nirK } & Temp & 0.19 & 19 & 2.08 & 0.020 \\
\hline & DO & 0.13 & 13 & 1.46 & 0.054 \\
\hline & Total $N$ & 0.14 & 14 & 1.54 & 0.240 \\
\hline & All the above together & 0.92 & 92 & & \\
\hline \multirow{4}{*}{ nirs } & Temp & 0.18 & 18 & 1.93 & 0.066 \\
\hline & $\mathrm{pH}$ & 0.10 & 10 & 1.19 & 0.304 \\
\hline & DO & 0.08 & 8 & 0.96 & 0.038 \\
\hline & All the above together & 0.69 & 69 & & \\
\hline \multirow{4}{*}{ nos $Z$} & Temp & 0.22 & 22 & 2.50 & 0.032 \\
\hline & $\mathrm{pH}$ & 0.11 & 11 & 1.41 & 0.082 \\
\hline & Total $N$ & 0.13 & 13 & 1.39 & 0.260 \\
\hline & All the above together & 0.79 & 79 & & \\
\hline
\end{tabular}

Partial RDAs based on Monte Carlo permutation $(n=499)$ kept only the significant water properties in the models. For each partial model, the other significant water properties were used as covariables. $F$ and $P$ values were estimated using Monte Carlo permutations. Sum of all eigenvalues for both partial RDAs was 1.000 .

resulting in considerable improvement of water quality in aquatic ecosystem [15]. Denitrifiers play an important role in buffering of the excessive load of nitrogen from upstream to downstream [16]. In aquatic ecosystems, mats of macrophytes are important sites for microbial mediated biogeochemical processes, as accrual of biomass and increases in mat density reduce the degree of external factors to influence internal processes [17]. The suspended root system of E. crassipes could provide a large surface area, approximately 2.5 to $8.0 \mathrm{~m}^{2} \mathrm{~kg}^{-1}$ on a dry weight basis, for microbial attachment $[5,18]$. Releasing of oxygen and dissolved organic carbon from roots of E. crassipes would support an appropriate microenvironment for nitrification and/or denitrification [19, 20].

Process of denitrification is driven by the denitrifying microorganisms under the influence of environmental conditions. Water properties in different rivers in the present study were shown altering the abundance and diversity of denitrifiers on E. crassipes roots.

4.1. Differential Characteristics of Different Rivers Impact the Abundance of Denitrifier on the Roots. The abundance of nirK, nirS, and nosZ denitrifiers on the root of macrophytes varied with the variation of environmental parameters in different rivers, which seemed depending on the nitrogen concentrations, water temperature [21], water turbulence, and pretreatment of wastewater using wetland.

The abundance of nirK, nirS, and nos $Z$ denitrifiers on root samples from $\mathrm{XBX}, \mathrm{DG}, \mathrm{CF}$, and PLJ rivers was relatively stable and low. These rivers were larger than other rivers around Dianchi Lake [22], which were important sites receiving effluent from the STPs. The fast-flowing water 


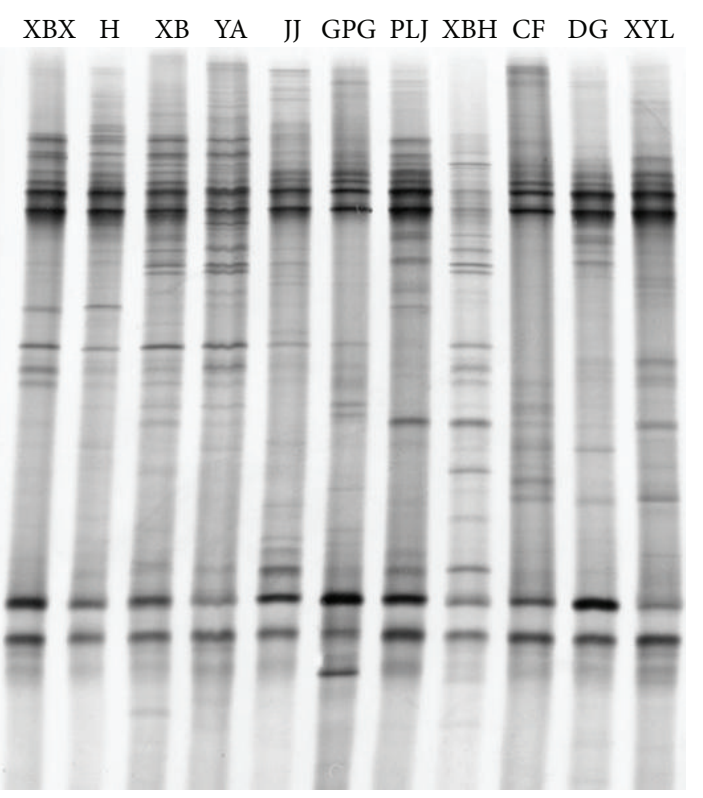

(a)

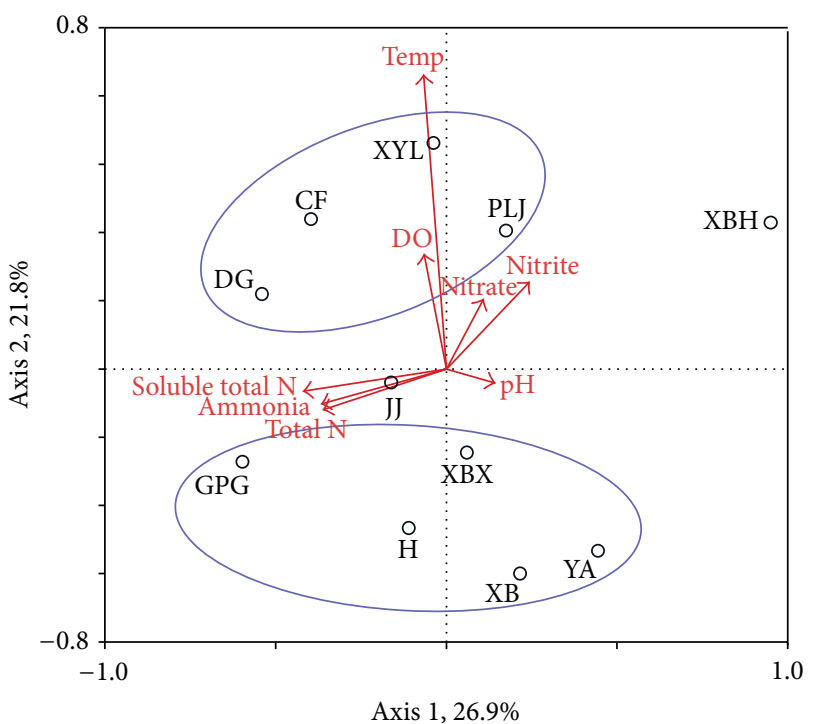

(b)

FIGURE 4: DGGE fingerprints and the redundancy analysis of DGGE band data of nirK gene. Arrows represent quantitative variables of environmental variables and small circles with letters represent the name of sample rivers; river names: $\mathrm{XBX}=$ Xinbaoxiang, $\mathrm{DG}=$ Daguang, $\mathrm{CF}=$ Chuangfang, $\mathrm{PLJ}=$ Panlongjiang, $\mathrm{H}=$ Haiheriver, $\mathrm{GPG}=$ Guangpugou, $\mathrm{JJ}=$ Jinjia $, \mathrm{XBH}=\mathrm{Xibahe}, \mathrm{XYL}=$ Xinyunling, $\mathrm{XB}=\mathrm{Xiaba}$, and $\mathrm{YA}=$ Yaoan.

and irregular discharge of effluent of these rivers [22] may prevent development of the stable environment properties from microbial attachment and propagate. Contrarily, the abundance of denitrifiers genes on roots samples in $\mathrm{XB}$ and YA rivers (Xiaba and Yaoan rivers) was higher than that in other rivers. The $\mathrm{XB}$ river received both the wastewater from industrial and residential areas and the tidal water from Dianchi Lake, when water level increased in rainy seasons (May to October) [23]. The water merged at Wujia wetland,

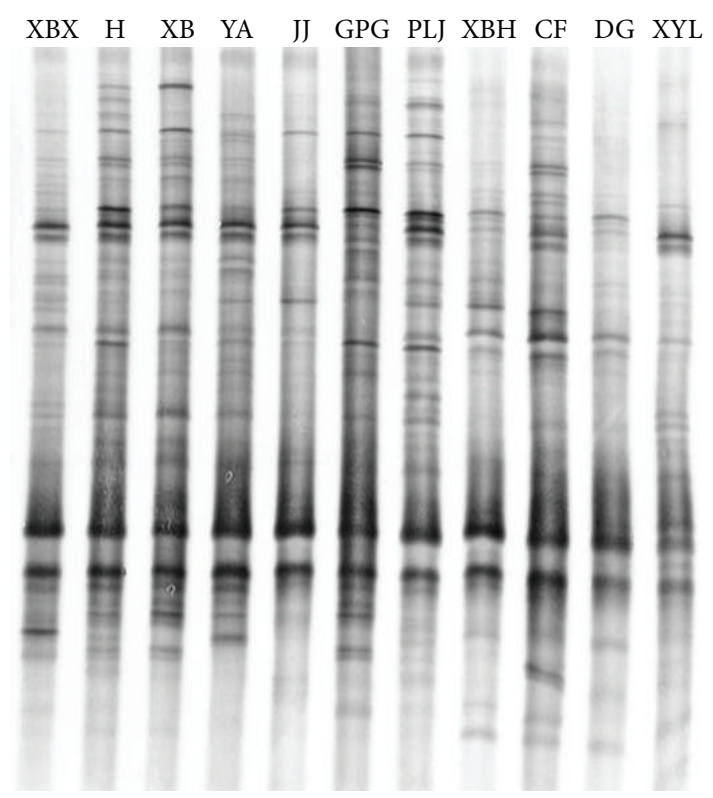

(a)

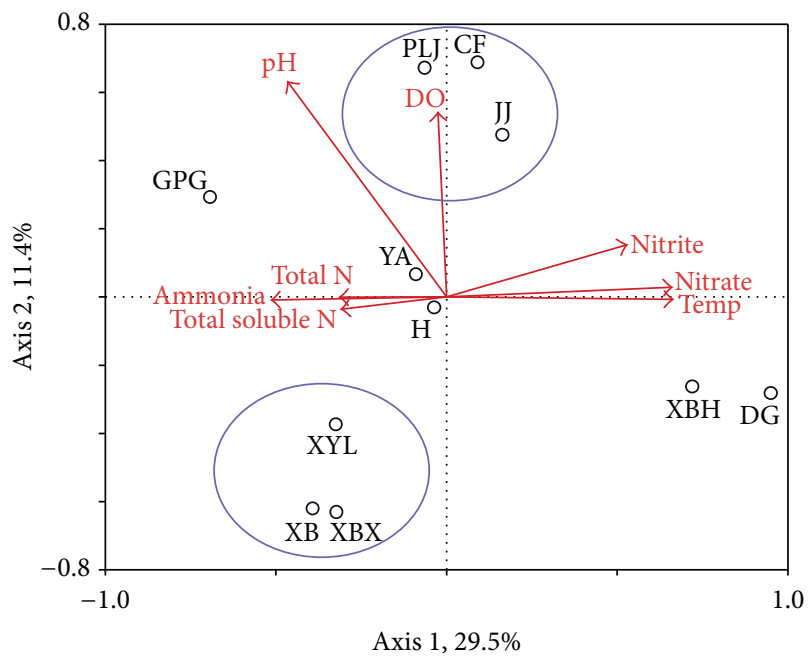

(b)

FIGURE 5: DGGE fingerprints and the redundancy analysis of DGGE band data of nirS gene. Arrows represent quantitative variables of environmental variables and small circles with letters represent the name of sample rivers; river names: $\mathrm{XBX}=$ Xinbaoxiang, $\mathrm{DG}=$ Daguang, $\mathrm{CF}=$ Chuangfang, $\mathrm{PLJ}=$ Panlongjiang, $\mathrm{H}=$ Haiheriver, $\mathrm{GPG}=$ Guangpugou, JJ = Jinjia, XBH = Xibahe, XYL = Xinyunling, $\mathrm{XB}=\mathrm{Xiaba}$, and $\mathrm{YA}=$ Yaoan .

and then part of it was pumped into YA river after 45 days of retention in Wujia wetland. This implies that a combination of wetland and growth of water hyacinth may further promote denitrification processes in eutrophic water.

The abundance of nirK gene was always greater than that of nirS gene on the roots of $E$. crassipes, suggesting that the fresh water of Dianchi lake was more suitable for the growth of nirK-type denitrifying bacteria. This was different from the previous reports [24]. The nirS gene of cytochrome $c d 1$ type has also been found more often in anoxic locations, where DO 


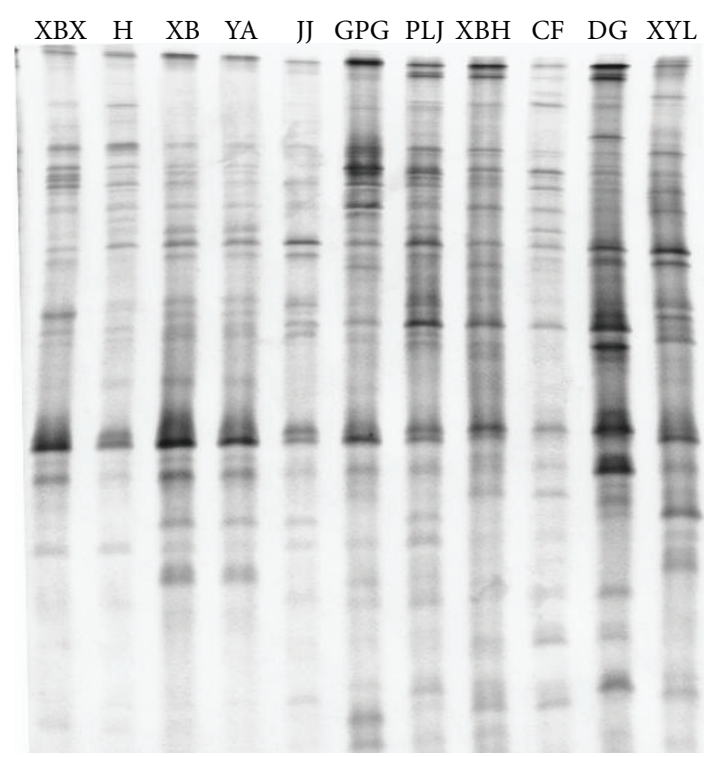

(a)

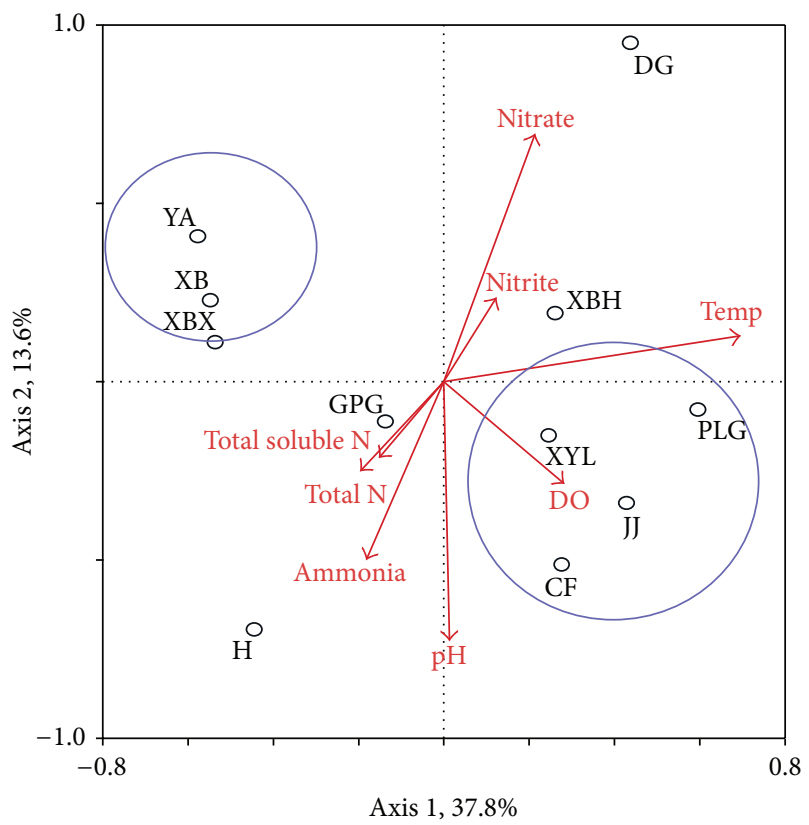

(b)

FIGURE 6: DGGE fingerprints and the redundancy analysis of DGGE band data of nos $Z$ gene. Arrows represent quantitative variables of environmental variables and small circles with letters represent the name of sample rivers; river names: $\mathrm{XBX}=$ Xinbaoxiang, $\mathrm{DG}=$ Daguang, $\mathrm{CF}=$ Chuangfang, $\mathrm{PLJ}=$ Panlongjiang, $\mathrm{H}=$ Haiheriver, $\mathrm{GPG}=$ Guangpugou, $\mathrm{JJ}=$ Jinjia, $\mathrm{XBH}=\mathrm{Xibahe}, \mathrm{XYL}=$ Xinyunling, $\mathrm{XB}=\mathrm{Xiaba}$, and $\mathrm{YA}=$ Yaoan.

levels were consistently low. In contrast, nirK genes of copper containing type have been found where diurnal DO swings are greater $[24,25]$. This finding was of coincidence with that E. crassipes releases oxygen from roots, which facilitates the creation of aerobic microsites on the roots [26]. Even though the nirK and nirS are functionally equivalent, denitrifying bacteria harboring either nitrite reductase seems to be likely not under the same community assembly rules [27]. Philippot et al. [28] suggested that the existence of the two types of nitrite reductase (nir-gene) was due to differential niche preferences. This speculation was consistent with previously identified habitat preferences of nirS-gene and nirK-gene bearing organisms [29]. Moreover, nirK and nirS sequences may come from different sources. Jones and Hallin [27] found that most nirK sequences were derived from soil but that most nirS sequences were prominently derived from marine and estuarine environment. Bacteria suspended in water and attached to the root of E. crassipes may originate from many different sources. Autochthonous bacterioplankton populations that developed in the water column were likely to be mixed with allochthonous populations from forest soils, urbanized land, farm fields, and wetlands as well as hyporheic sediments in the rivers. This mixed origination, impacted by varied environmental parameters, seemed to be the main cause of the discrepancy of denitrifiers found in the eleven rivers. This, however, did not necessarily indicate that nirKtype denitrifiers contributed more or less in denitrification than nirS-type ones; rather it may only imply that the root of E. crassipes could provide a broad support for different kinds of microorganisms.

4.2. Relationship between Environmental Factors and Community Compositions of Denitrifying Genes on E. crassipes Root at Different Rivers. Dianchi Lake together with surrounding rivers comprised a plateau water catchment to provide ecological services and fresh water supply for more than seven million people in the area. Its geochemical characteristics have made the water $\mathrm{pH}$ relatively high (7.56-8.03) and its geophysical characteristics have made the water temperature moderate with winter months (December to March next year) around $12^{\circ} \mathrm{C}$. Its heavy load of organic matters have made the DO level relatively low $\left(0.20-3.80 \mathrm{mg} \mathrm{L}^{-1}\right)$ in the 11 rivers investigated. These environmental properties dominated the community assembly processes of the genetic makeup of the denitrifiers in the rivers. Nevertheless, specific environmental conditions in different rivers favored the variation in richness and diversity of different denitrifying genes.

The DGGE profiles for denitrification genes encoding nitrite and nitrous oxide reductase (nirK, nirS, and nos Z) on the root of E. crassipes growing in 11 rivers around Dianchi Lake supported our hypothesis of profound differences in community composition, although a complex picture of denitrifier community similarity emerged depending on which functional denitrification gene was evaluated. The correlations of denitrifying microbial community compositions with abiotic environmental factors, using redundancy analysis (RDA), confirmed that water temperature (Temp), dissolved oxygen (DO), and $\mathrm{pH}$ appeared to be the most important factors to alter the denitrifier community structures significantly by serving as essential conditions for the growth of microorganisms on the roots of E. crassipes (Table 5).

The results of this study indicated that the development of denitrifier communities on roots corresponded to different origins of rivers. The physiochemical characteristics of water from the river inlet varied with water origin and pollution 
sources $[22,23,30]$, resulting in the variation in $\mathrm{DO}, \mathrm{pH}$, pollutant species and concentrations, and organic carbons in rivers. These environmental factors, including DO, carbon content, water temperature, and $\mathrm{pH}$, influenced denitrification rates in rivers [31] and as a consequence they might also affect the denitrifier community composition [32,33]. Braker et al. [34] found that the change of temperature resulted in gradually changed denitrification activity but also in abundance mutative of nitrate reducers and in different denitrifier community compositions. There are some indications that temperature and $\mathrm{pH}$ may directly or indirectly influence the abundance and communities composition of denitrifiers [35, 36]. The excess $\mathrm{O}_{2}$ resulted in reduced denitrifying bacterial growth and a smaller bacterial density versus nitrate reducing bacteria ration [37], which indicated that the development of the denitrifying bacteria was influenced by the DO concentration. Many investigators had found that the $\mathrm{pH}$, temperature, and DO generally affect diversity and richness of denitrifier community [32, 38], and microbial community assembly was more dependent on local-scale environmental factors [39].

On the other hand, different microorganisms may have their physiological constraints for growth and reproduction within narrow $\mathrm{pH}$ ranges, specific $\mathrm{DO}$, and nutrient availability, which affect the community structures directly $[40,41]$. Activities of microorganisms could change the environmental properties that differed in the concentrations of enzymes and nutrients or DO, the form and amount of dissolved carbon present, and $\mathrm{pH}$ [42] hence to affect denitrifier community structure. Previous studies have found that growth of E. crassipes could regulate water at neutralize $\mathrm{pH}$ significantly [43], as a result of increase in the rate of denitrification in aquatic ecosystems [44].

\section{Conclusions}

The variation in abundance of denitrifier communities on E. crassipes roots, grown in rivers flowing into Dianchi Lake, corresponded to different water properties of rivers. The ratio of nirK/nirS gene copies abundance was always greater than 1, indicating that the surface of E. crassipes roots was more suitable for the growth of nirK-type denitrifying bacteria. The temperature of water, nitrate concentration, and $\mathrm{pH}$ greatly affected the nirS, nirK, and nos $\mathrm{Z}$ abundance than other factors. Meanwhile, the temperature of water, $\mathrm{DO}$, and $\mathrm{pH}$ appeared to be the most important factors to alter the community structures of denitrifiers on the roots of $E$. crassipes. As process of denitrification is driven by denitrifies under the influence of environmental conditions, a variation of denitrification capability in different rivers would be expected.

\section{Conflict of Interests}

The authors declare that there is no conflict of interests regarding the publication of this paper.

\section{Authors' Contribution}

Neng Yi and Yan Gao contributed equally to this work.

\section{Acknowledgments}

The authors are grateful for the financial support from State Natural Science Foundation of China (no. 41401592), Natural Science Foundation of Jiangsu Province (no. BK20140737), and Independent Innovation of Agricultural Sciences in Jiangsu Province (no. CX(14)5047) and Jiangsu Province Science and Technology Support Plan Project (BE2013436).

\section{References}

[1] M. H. Hu, Y. S. Ao, X. E. Yang, and T. Q. Li, “Treating eutrophic water for nutrient reduction using an aquatic macrophyte (Ipomoea aquatica Forsskal) in a deep flow technique system," Agricultural Water Management, vol. 95, no. 5, pp. 607-615, 2008.

[2] Q. Yi, Y. Kim, and M. Tateda, "Evaluation of nitrogen reduction in water hyacinth ponds integrated with waste stabilization ponds," Desalination, vol. 249, no. 2, pp. 528-534, 2009.

[3] M. Rodríguez, J. Brisson, G. Rueda, and M. S. Rodríguez, "Water quality improvement of a reservoir invaded by an exotic macrophyte," Invasive Plant Science and Management, vol. 5, no. 2, pp. 290-299, 2012.

[4] Z. Wang, Z. Zhang, J. Zhang, Y. Zhang, H. Liu, and S. Yan, "Large-scale utilization of water hyacinth for nutrient removal in Lake Dianchi in China: the effects on the water quality, macrozoobenthos and zooplankton," Chemosphere, vol. 89, no. 10, pp. 1255-1261, 2012.

[5] N. Yi, Y. Gao, X.-H. Long et al., "Eichhornia crassipes cleans wetlands by enhancing the nitrogen removal and modulating denitrifying bacteria community," CLEAN-Soil, Air, Water, vol. 42, no. 5, pp. 664-673, 2014.

[6] Y. Gao, N. Yi, Y. Wang et al., "Effect of Eichhornia crassipes on production of $\mathrm{N}_{2}$ by denitrification in eutrophic water," Ecological Engineering, vol. 68, pp. 14-24, 2014.

[7] V. Gagnon, F. Chazarenc, Y. Comeau, and J. Brisson, "Influence of macrophyte species on microbial density and activity in constructed wetlands," Water Science and Technology, vol. 56, no. 3, pp. 249-254, 2007.

[8] R. D. Sooknah and A. C. Wilkie, "Nutrient removal by floating aquatic macrophytes cultured in anaerobically digested flushed dairy manure wastewater," Ecological Engineering, vol. 22, no. 1, pp. 27-42, 2004.

[9] J. Green and B. J. M. Bohannan, "Spatial scaling of microbial biodiversity," Trends in Ecology \& Evolution, vol. 21, no. 9, pp. 501-507, 2006.

[10] C. L. Lauber, M. Hamady, R. Knight, and N. Fierer, "Pyrosequencing-based assessment of soil $\mathrm{pH}$ as a predictor of soil bacterial community structure at the continental scale," Applied and Environmental Microbiology, vol. 75, no. 15, pp. 5111-5120, 2009.

[11] D. Radojkovic and J. Kušic, "Silver staining of denaturing gradient gel electrophoresis gels," Clinical Chemistry, vol. 46, no. 6, pp. 883-884, 2000.

[12] H. F. Luo, H. Y. Qi, and H. X. Zhang, "Assessment of the bacterial diversity in fenvalerate-treated soil," World Journal 
of Microbiology and Biotechnology, vol. 20, no. 5, pp. 509-515, 2004.

[13] D. Roesti, R. Gaur, B. N. Johri et al., "Plant growth stage, fertiliser management and bio-inoculation of arbuscular mycorrhizal fungi and plant growth promoting rhizobacteria affect the rhizobacterial community structure in rain-fed wheat fields," Soil Biology and Biochemistry, vol. 38, no. 5, pp. 1111-1120, 2006.

[14] J. Lepš and P. Šmilauer, Multivariate Analysis of Ecological Data using CANOCO, Cambridge University Press, Cambridge, UK, 2003.

[15] A. J. Burgin and S. K. Hamilton, "Have we overemphasized the role of denitrification in aquatic ecosystems? A review of nitrate removal pathways," Frontiers in Ecology and the Environment, vol. 5, no. 2, pp. 89-96, 2007.

[16] A. C. Mosier and C. A. Francis, "Denitrier abundance and activity across the San Francisco Bay estuary," Environmental Microbiology Reports, vol. 2, no. 5, pp. 667-676, 2010.

[17] E. Lyautey, S. Hallin, S. Teissier et al., "Abundance, activity and structure of denitrifier communities in phototrophic river biofilms (River Garonne, France)," Hydrobiologia, vol. 716, no. 1, pp. 177-187, 2013.

[18] Y. Kim and W.-J. Kim, "Roles of water hyacinths and their roots for reducing algal concentration in the effluent from waste stabilization ponds," Water Research, vol. 34, no. 13, pp. 32853294,2000

[19] S. Kouki, N. Saidi, A. B. Rajeb et al., "Potential of a polyculture of Arundo donax and Typha latifolia for growth and phytotreatment of wastewater pollution," African Journal of Biotechnology, vol. 11, no. 87, pp. 15341-15352, 2012.

[20] C. C. Tanner, "Plants for constructed wetland treatment systems-a comparison of the growth and nutrient uptake of eight emergent species," Ecological Engineering, vol. 7, no. 1, pp. 59-83, 1996.

[21] A. M. Baxter, L. Johnson, T. Royer, and L. G. Leff, "Spatial differences in denitrification and bacterial community structure of streams: relationships with environmental conditions," Aquatic Sciences, vol. 75, no. 2, pp. 275-284, 2013.

[22] B. Wang, B. Huang, W. Jin et al., "Occurrence, distribution, and sources of six phenolic endocrine disrupting chemicals in the 22 river estuaries around Dianchi Lake in China," Environmental Science and Pollution Research, vol. 20, no. 5, pp. 3185-3194, 2013.

[23] Y. Huang, H. Wen, J. Cai et al., "Key aquatic environmental factors affecting ecosystem health of streams in the Dianchi Lake Watershed, China," Procedia Environmental Sciences, vol. 2, pp. 868-880, 2010.

[24] C. W. Knapp, W. K. Dodds, K. C. Wilson, J. M. O’Brien, and D. W. Graham, "Spatial heterogeneity of denitrification genes in a highly homogenous urban stream," Environmental Science \& Technology, vol. 43, no. 12, pp. 4273-4279, 2009.

[25] A. García-Lledó, A. Vilar-Sanz, R. Trias, S. Hallin, and L. Bañeras, "Genetic potential for $\mathrm{N}_{2} \mathrm{O}$ emissions from the sediment of a free water surface constructed wetland," Water Research, vol. 45, no. 17, pp. 5621-5632, 2011.

[26] K. K. Moorhead and K. R. Reddy, "Oxygen transport through selected aquatic macrophytes," Journal of Environmental Quality, vol. 17, no. 1, pp. 138-142, 1988.

[27] C. M. Jones and S. Hallin, "Ecological and evolutionary factors underlying global and local assembly of denitrifier communities," The ISME Journal, vol. 4, no. 5, pp. 633-641, 2010.
[28] L. Philippot, J. Čuhel, N. P. A. Saby et al., "Mapping fieldscale spatial patterns of size and activity of the denitrifier community," Environmental Microbiology, vol. 11, no. 6, pp. 1518-1526, 2009.

[29] C. Desnues, V. D. Michotey, A. Wieland et al., "Seasonal and diel distributions of denitrifying and bacterial communities in a hypersaline microbial mat (Camargue, France)," Water Research, vol. 41, no. 15, pp. 3407-3419, 2007.

[30] Y. J. Yu, J. Guan, Y. W. Ma et al., "Aquatic environmental quality variation in Dianchi lake watershed," Procedia Environmental Sciences, vol. 2, pp. 76-81, 2010.

[31] J. L. Baeseman, R. L. Smith, and J. Silverstein, "Denitrification potential in stream sediments impacted by acid mine drainage: effects of $\mathrm{pH}$, various electron donors, and iron," Microbial Ecology, vol. 51, no. 2, pp. 232-241, 2006.

[32] B. C. Crump and J. E. Hobbie, "Synchrony and seasonality in bacterioplankton communities of two temperate rivers," Limnology and Oceanography, vol. 50, no. 6, pp. 1718-1729, 2005.

[33] Z. H. Liu, S. B. Huang, G. P. Sun, Z. Xu, and M. Xu, "Phylogenetic diversity, composition and distribution of bacterioplankton community in the Dongjiang River, China," FEMS Microbiology Ecology, vol. 80, no. 1, pp. 30-44, 2012.

[34] G. Braker, J. Schwarz, and R. Conrad, "Influence of temperature on the composition and activity of denitrifying soil communities," FEMS Microbiology Ecology, vol. 73, no. 1, pp. 134-148, 2010.

[35] M. D. Wallenstein, D. D. Myrold, M. Firestone, and M. Voytek, "Environmental controls on denitrifying communities and denitrification rates: insights from molecular methods," Ecological Applications, vol. 16, no. 6, pp. 2143-2152, 2006.

[36] J. K. M. Walker, K. N. Egger, and G. H. R. Henry, "Long-term experimental warming alters nitrogen-cycling communities but site factors remain the primary drivers of community structure in high arctic tundra soils," The ISME Journal, vol. 2, no. 9, pp. 982-995, 2008.

[37] M. A. Gómez, E. Hontoria, and J. González-López, “Effect of dissolved oxygen concentration on nitrate removal from groundwater using a denitrifying submerged filter," Journal of Hazardous Materials, vol. 90, no. 3, pp. 267-278, 2002.

[38] S. Hallin, C. M. Jones, M. Schloter, and L. Philippot, "Relationship between $\mathrm{n}$-cycling communities and ecosystem functioning in a 50-year-old fertilization experiment," The ISME Journal, vol. 3, no. 5, pp. 597-605, 2009.

[39] W. H. Hartman, C. J. Richardson, R. Vilgalys, and G. L. Bruland, "Environmental and anthropogenic controls over bacterial communities in wetland soils," Proceedings of the National Academy of Sciences of the United States of America, vol. 105, no. 46, pp. 17842-17847, 2008.

[40] I. R. Booth, "Regulation of cytoplasmic pH in bacteria," Microbiological Reviews, vol. 49, no. 4, pp. 359-378, 1985.

[41] W. Stumm and J. J. Morgan, Aquatic Chemistry: Chemical Equilibria and Rates in Natural Waters, John Wiley \& Sons, New York, NY, USA, 2012.

[42] M. Kühl, L. F. Rickelt, and R. Thar, "Combined imaging of bacteria and oxygen in biofilms," Applied and Environmental Microbiology, vol. 73, no. 19, pp. 6289-6295, 2007.

[43] C. McVea and C. E. Boyd, "Effects of waterhyacinth cover on water chemistry, phytoplankton, and fish in ponds," Journal of Environmental Quality, vol. 4, no. 3, pp. 375-378, 1975.

[44] S. R. Carrino-Kyker, K. A. Smemo, and D. J. Burke, "The effects of $\mathrm{pH}$ change and $\mathrm{NO}_{3}^{-}$pulse on microbial community 
structure and function: a vernal pool microcosm study," FEMS Microbiology Ecology, vol. 81, no. 3, pp. 660-672, 2012.

[45] K. Kloos, A. Mergel, C. Rösch, and H. Bothe, "Denitrification within the genus Azospirillum and other associative bacteria," Australian Journal of Plant Physiology, vol. 28, no. 9, pp. 991998, 2001.

[46] I. N. Throbäck, K. Enwall, Å. Jarvis, and S. Hallin, "Reassessing PCR primers targeting nirS, nirK and nosZ genes for community surveys of denitrifying bacteria with DGGE," FEMS Microbiology Ecology, vol. 49, no. 3, pp. 401-417, 2004.

[47] V. Michotey, V. Méjean, and P. Bonin, "Comparison of methods for quantification of cytochrome cd1-denitrifying bacteria in environmental marine samples," Applied and Environmental Microbiology, vol. 66, no. 4, pp. 1564-1571, 2000.

[48] G. Braker and J. M. Tiedje, "Nitric oxide reductase (norB) genes from pure cultures and environmental samples," Applied and Environmental Microbiology, vol. 69, no. 6, pp. 3476-3483, 2003.

[49] S. Hallin and P.-E. Lindgren, "PCR detection of genes encoding nitrite reductase in denitrifying bacteria," Applied and Environmental Microbiology, vol. 65, no. 4, pp. 1652-1657, 1999. 

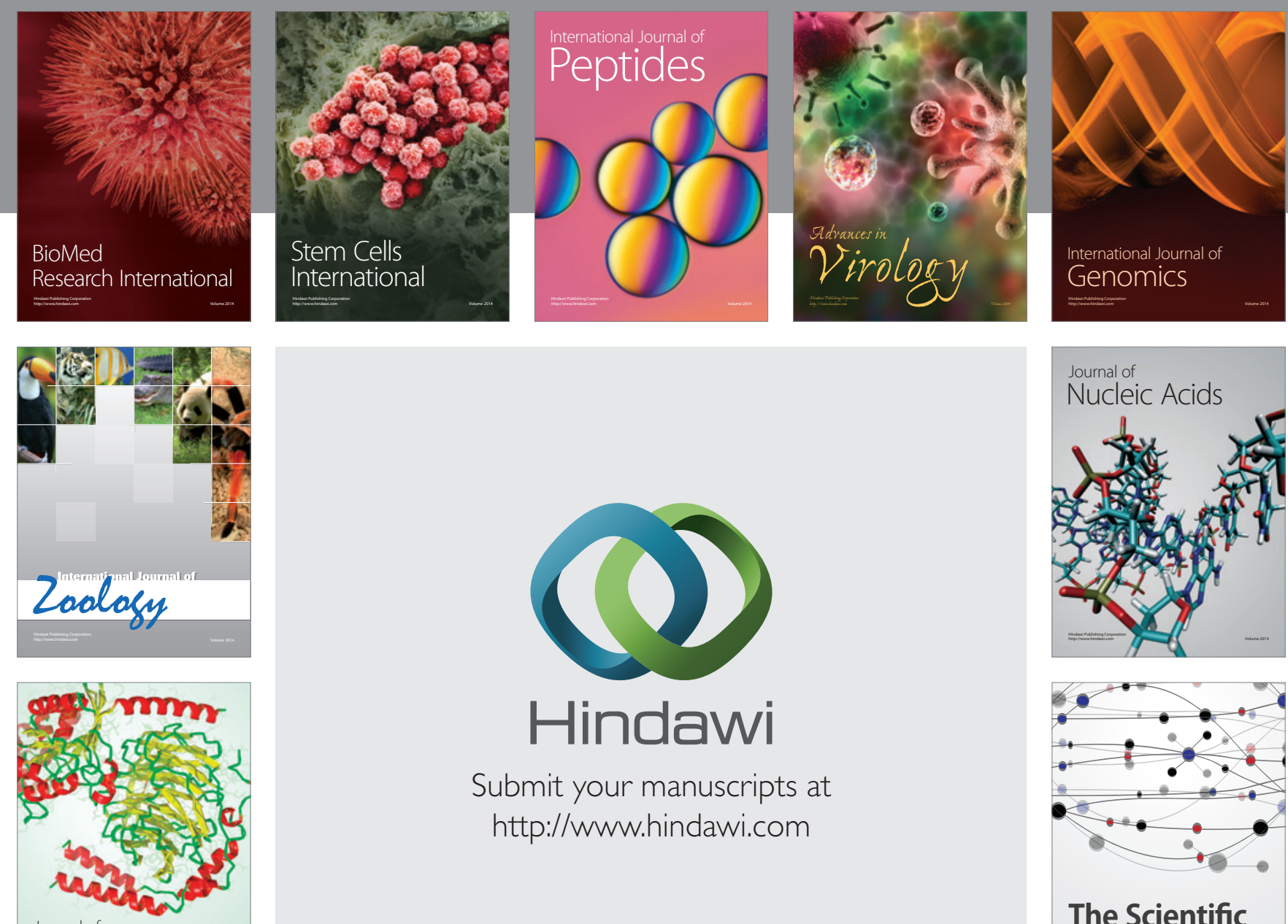

Submit your manuscripts at

http://www.hindawi.com

Journal of
Signal Transduction
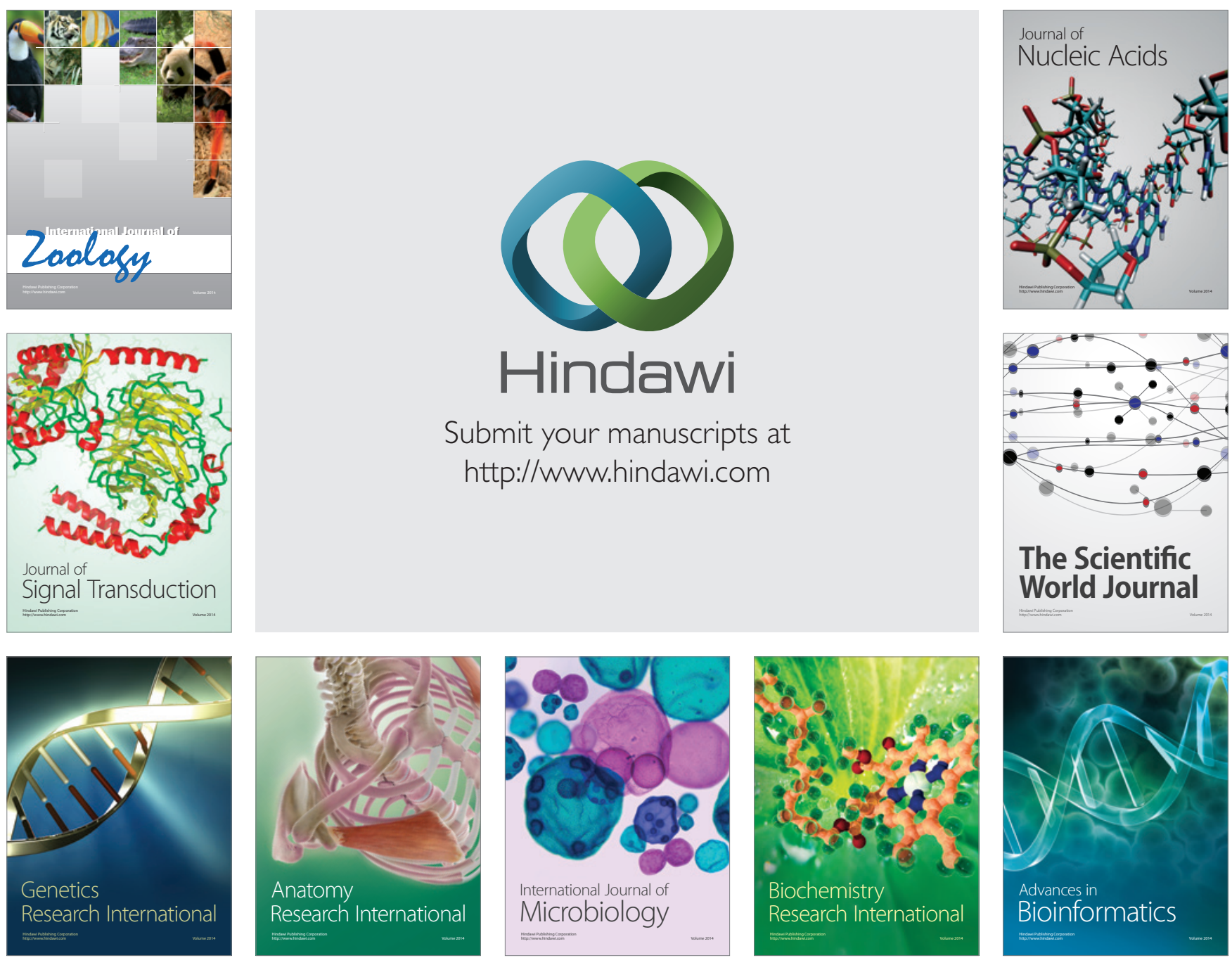

The Scientific World Journal
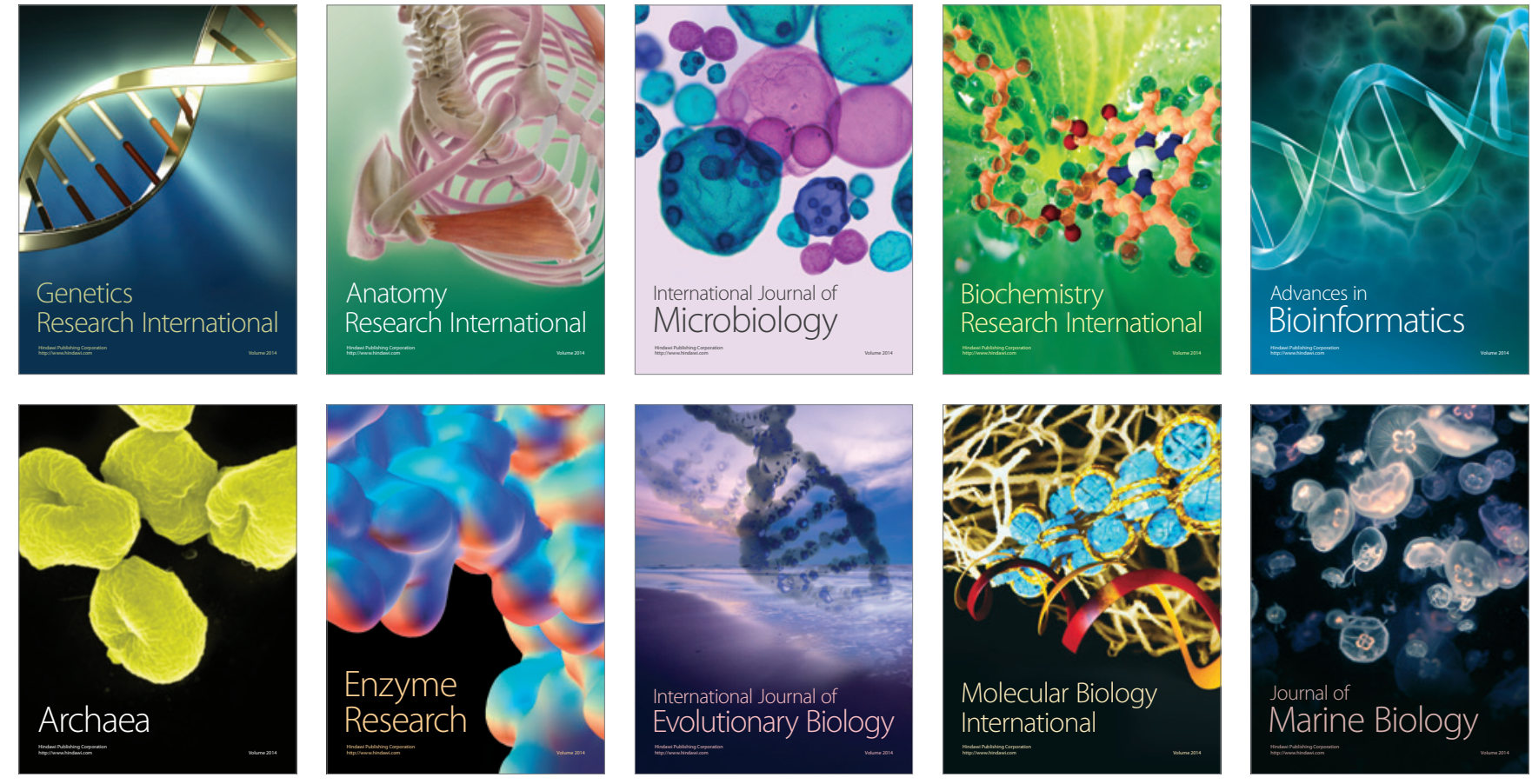